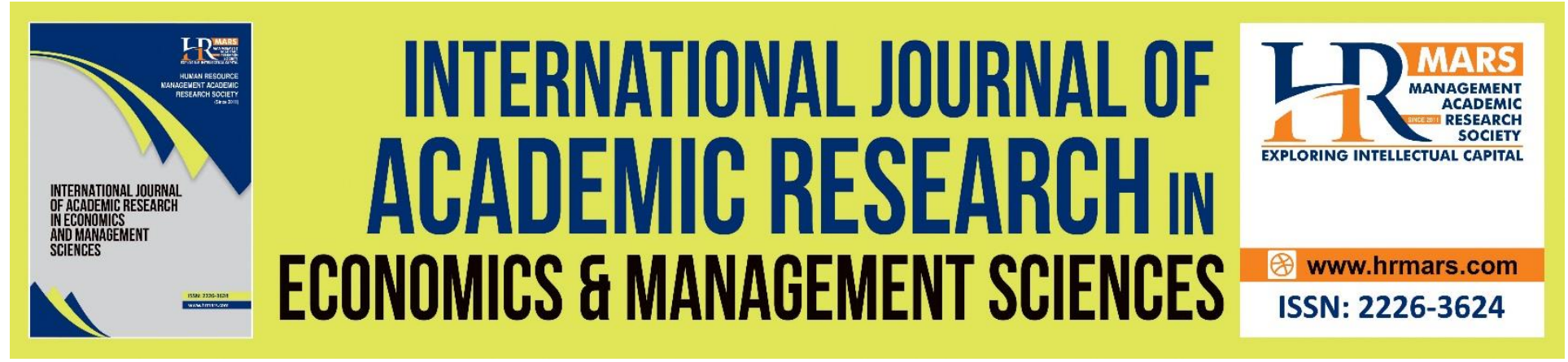

\title{
Does Corruption Caused Income Inequality in Indonesia?
}

\section{Ahmadshah Sani, Abdul Rahim Ridzuan, Ab Rahman, Z.}

To Link this Article: http://dx.doi.org/10.6007/IJAREMS/v9-i2/7344

DOI: $10.6007 /$ IJAREMS/v9-i2/7344

Received: 25 March 2020, Revised: 29 April 2020, Accepted: 26 May 2020

Published Online: 20 June 2020

In-Text Citation: (Sani et al., 2020)

To Cite this Article: Sani, A., Ridzuan, A. R., \& Ab Rahman, Z. (2020). Does Corruption Caused Income Inequality in Indonesia? International Journal of Academic Research Economics and Managment and Sciences, 9(2), 1730 .

Copyright: (C) 2020 The Author(s)

Published by Human Resource Management Academic Research Society (www.hrmars.com)

This article is published under the Creative Commons Attribution (CC BY 4.0) license. Anyone may reproduce, distribute, translate and create derivative works of this article (for both commercial and non-commercial purposes), subject to full attribution to the original publication and authors. The full terms of this license may be seen at: http://creativecommons.org/licences/by/4.0/legalcode

Vol. 9, No. 2, 2020, Pg. 17 - 30

http://hrmars.com/index.php/pages/detail/IJAREMS

JOURNAL HOMEPAGE

Full Terms \& Conditions of access and use can be found at http://hrmars.com/index.php/pages/detail/publication-ethics 


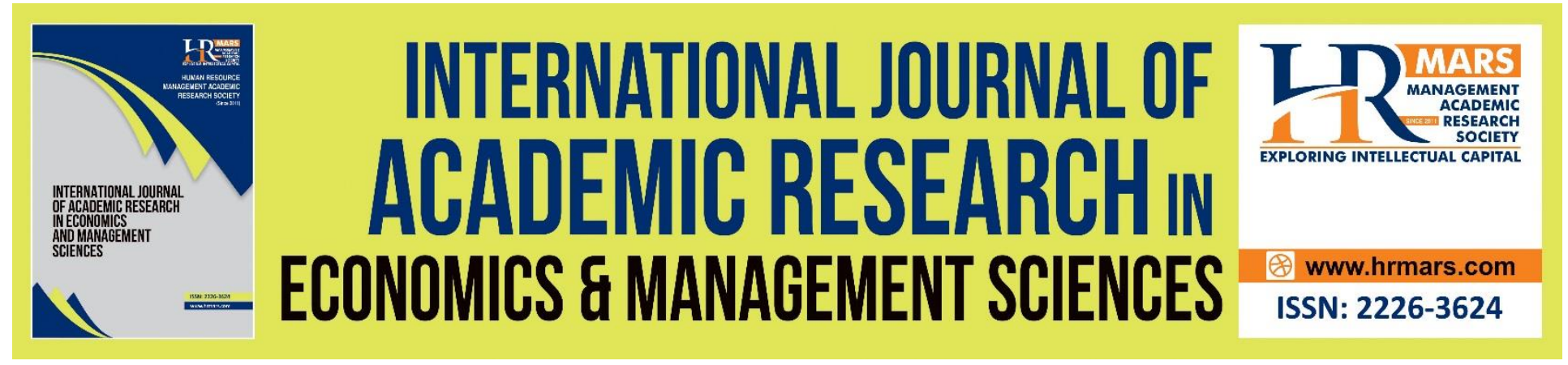

\title{
Does Corruption Caused Income Inequality in Indonesia?
}

\author{
Ahmadshah Sani, Abdul Rahim Ridzuan \\ Faculty of Business and Management, Universiti Teknologi MARA, Melaka Campus, Malaysia \\ Email: ahmadsufi161@gmail.com, Rahim670@staf.uitm.edu.my \\ Ab Rahman, Z. \\ Research Centre for Theology \& Philosophy, Faculty of Islamic Studies, Universiti Kebangsaan \\ Malaysia, Malaysia \\ Email: zaizul@ukm.edu.my
}

\begin{abstract}
This paper investigated the effect on income distribution in Indonesia with related variables from the period 1984 to 2017 using annual data. Gross domestic product, inflation, corruption, foreign direct investment, and trade openness are the selected variables that have been chosen in this study. The study implements Autoregressive Distributed Lag (ARDL) estimation to investigate the short-run and long-run elasticities of the proposed model. The results from the Augmented Dickey-Fuller and Phillips-Perron tests of stationarity indicated that all the variables were nonstationary at the level I (o) but stationary at the first difference I (1). The finding based on longrun elasticities reveals that the result of the ARDL model exposes that all variables except for inflation have significantly influence inequality of income distribution in Indonesia. The government needs to initiate policies that will facilitate the improvement of the income distribution of their country.
\end{abstract}

Keywords: Income Distribution, ARDL, Gross Domestic Product, Corruption, Foreign Direct Investment

\section{Introduction}

Income inequality refers to differences in money earned and general well-being standards among individual groups. This group is studied mostly or to groups within, or even individuals within, local, national, and regional populations (Atkinson, 2015). The world is experiencing a two-fold change with decreases in inequality between countries and increases in inequality within the region. Whereas the level of global inequality has declined over the past decade by over $5 \%$, due to rapid development in emerging economies, income inequality in almost every country has increased sharply (Bourguignon, 1979). This research paper will use the Gini index in Indonesia to investigate the factor for income inequality in Indonesia. The gap between the richest and the 
other in Indonesia has grown more rapidly over the last two decades than any other country in Southeast Asia. It is now the sixth country of the greatest wealth inequality in the world. Indonesia has experienced decent economic growth, both in terms of plentiful reserves of natural resources and a strong workforce (Mc Kinsey Global Institute 2012). In a developing country, increasing inequality is an important problem and Indonesia is no exception. Today Indonesia's four richest men are richer than the average of the 100 million poorest. The reduction of the income distribution difference between those at the top and bottom has become a major concern of the government. The sources of income inequality must be appropriately identified to achieve the objective of this paper.

This paper focuses on one main possible indictor that causes inequality of income distribution in Indonesia which is corruption. Corruption is one of the world economy's greatest problems. Such cases represent $35 \%$ of all job-related defrauds with an estimated economic loss of Rp 2.7 billion. The latest data reveals that cases of corruption are rising in Indonesia. With a total of 3109 convicted persons in the last 15 years and financial losses of Rp 40.6 billion on average each year, the number of convicted persons in corruption has risen approximately 38 percent. Compared to the other countries, Indonesia placed 90th from 176 countries in the Corruption Perception Index (CPI) of 37. In January 2012, Indonesia lost Rp 2.13 trillion (US\$238.6 million) as a consequence of corruption. In a report by the Non-Profit Indonesia Corruption Watches, organized by Danang Widoyoko, the misappropriation accounted for the majority of lost money, and "the most gratifying field was government investment. Approximately 1/4 of the ministries in Indonesia suffer from financial diversions. Households spend about $1 \%$ while companies invest a total of $5 \%$ of monthly company sales on unauthorized payments. The deterioration of government institutions and the rule of law have social costs due to corruption in Indonesia. The institutions are supposed to protect people are involved in growing corruption through smuggling and extort. The people who suffer the most are the poor because they have already limited budgets and pressurized to fund payments and the quality of social services is less indirectly available. The poor urban communities of Indonesia themselves expressed these concerns in a research project entitled "Corruption and the poor" by a joint World Bank Partnership for Governance Reform project.

Figure 1: Indonesia's corruption index

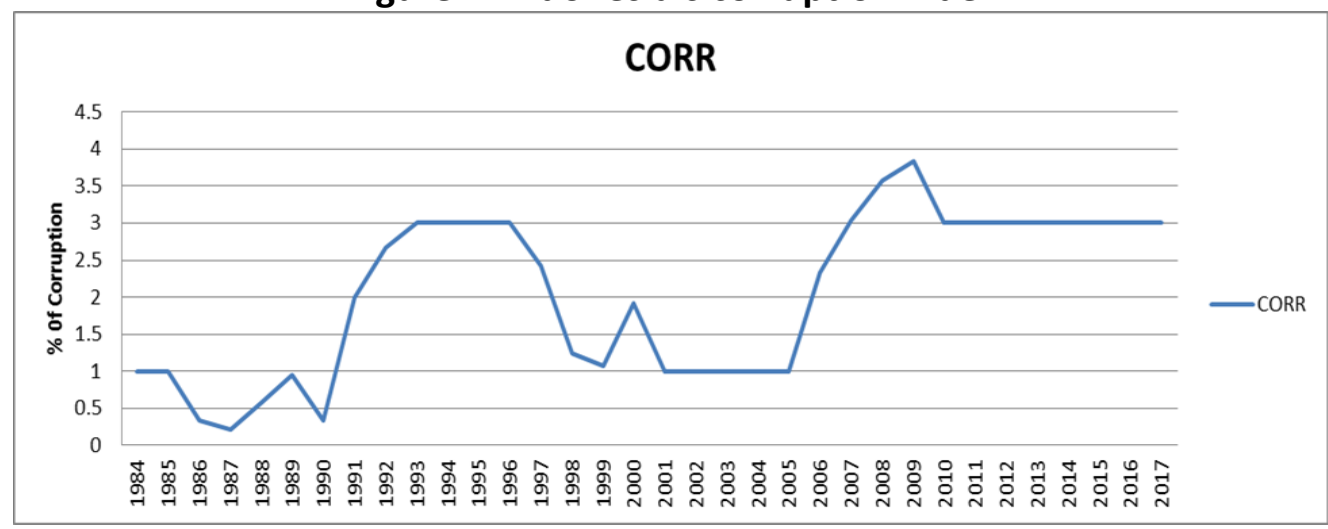

Source: World Bank Data 2018 
INTERNATIONAL JOURNAL OF ACADEMIC RESEARCH ECONOMICS AND MANAGEMENT SCIENCES Vol. 9, No. 2, 2020, E-ISSN: 2226-3624 @ 2020 HRMARS

\section{Literature Review}

This section is divided into two types of analysis: One is cross-country study and the second one is country-specific studies.

\section{Cross-country studies}

First, from Deyshappriya (2017) reviews income inequality determinants through a panel analysis of the data. In particular, the study uses the generalized method for analyzing panel data based on 33 Asian countries from 1990-2013. The World Bank data series was usually used as sources of data for macroeconomic variables while the World Income Inequality Database used to find the Gini index. In the report, a set of political-economic factors and demographic factors was also established, to complement the macroeconomic factors. In the study, the inverted U-shaped relationship between GDP and inequality was found, which supported the well-known Kuznets curve concept. GDP is one of the main income disparities in the Asian region, as a result of the paper. In particular, the InGDP (log of GDP) affects income inequality positively, while the InGDP square has a negative impact upon all three more statistically significant models. The connection between GDP and income inequalities shows a parabolic. However, income inequality may fall if GDP continues to increase over the long-term. Official development assistance (ODA), education and labor can also reduce inequality, and greater inflation, political risk, trade conditions, and unemployment in Asian countries will increase inequalities.

According to George (2017), the sample of the research consisted of 34 OECD countries and the data was collected to their income inequality and their GDP growth per capita. Specifically, the data were collected for four periods which is from 1995-2000, 2000-2005, 2005-2011 and overall from 1995-2011. Real per capita GDP in terms of growth has been employed to measure sample country growth. To measure inequality, the top and bottom end of the income distribution were both general inequality and inequality measured. By considering dummies, the findings of shortterm panel data analysis of the period 2005-2010 are similar to the results of Voitchovsky (2003) for the year 1975-2000 and found that there is no short-term disparity impact on economic growth. Regarding the results on 2005-2010, the value of Gini coefficient becomes negative, when the distribution top is monitored and the bottom inequality is monitored positively, is also same with the idea from Voitchovsky (2003) that consequence of serving as a proxy both for positive and negative effects of top and bottom disparity, Gini coefficient is insignificant. It is also consistent with Voitchovsky's (2003) study that the results are different when the top and the bottom inequality are investigated simultaneously. While long-term low-end inequality affects growth.

Next research from Eleftherios Thalassinos, Erginbay Uğurlu \& Yusuf Muratoğlu (2012), the main objective of the research is to show the relationship in 13 European between inflation and income inequality from 2000 to 2009 using panel data methodology. Income inequality is measured by the GINI coefficient while the independent variables are the inflation rate, the growth rate, the employment level, and the openness of the economies. Using panel data techniques, it has constructed a fixed effect model based on a Hausman test which is the same with past research and has found there is a positive relationship between income and inflation rate for the countries in. In addition, the employment rate, openness of the economy, and GDP 
are controlled variables which have been contained in the theoretical and empirical review and applications from recent literature. It's concluded that all control variables increase income inequality except GDP.

There is limited researcher research on corruption's effects on income inequality as stated by Li et al. (2000). Using data from mixed country groups, namely, low, medium, and high income, Li et al. (2000) also Chong and Calderon (2000a) observe an inverse U-shaped relationship between income inequality and corruption. They said that the relationship between income inequality and corruption is a negative relationship in low-income countries and positive in high-income countries. Gupta et al. (2002), founded different results when using smaller country samples which a positive and linear relationship between income inequality and corruption. Chong \& Calderon (2000b) and Gupta et al. (2002) both study about effects of corruption on poverty and income inequality. As Chong \& Calderon (2000b) stated that an increase in corruption will increase income inequality but does not means that increase poverty too.

\section{Country-specific Studies}

Next, this paper will discuss the finding on the time series method. The first research that found the relationship between inequality of income distribution with other variables are from Fatimah et al (2017), the purpose of this study is to study the existence in Malaysia of a long-run relationship between income inequality and economic growth. The period of the study from 1970-2014 and the analysis used annual time series data. The Autoregressive Distributive Lag (ARDL) is used in this study for the cointegration and error correction method (ECM), a testing approach for ARDL boundaries was used. The ADF unit root evaluation is used to deal with the root problem. The research analytical findings contrast the significant link between income inequality and economic growth. This research seems sometimes to be a strong and unique contribution to the literature concerning Malaysia to the best for the knowledge. This study is one of the pioneers using the ARDL cointegration approach in Malaysia for the problem of income inequality. The benchmark assessment and sensitivity analysis has demonstrated empirically that inequality can significantly in the short term and can be positively and insignificantly linked to economic growth. In Malaysia the initial GDP growth per capita will lead to an increase in income inequality, therefore supported the Kuznets hypothesis for income inequality and economic growth. Education ratios and foreign direct investment, in the long term and in the short term can reduce income inequality. However, openness to trade in the long term will increase income inequality.

In the second paper from Muhammad et. al (2011), the paper looks at the impact on income distribution in Pakistan of the nominal devaluation. This paper includes economic growth, per capita measurements, trade-openness, FDI, unemployment, and inflation levels, which are wellfounded in a particular context of the Pakistan economy. For the long term relationship and for the short term dynamics the Auto Regressive Distributed Lag (ARDL) testing approach is used for the cointegration and Vector Error Correction (VECM) approach. The inverted relations between income inequality and economic growth in the Kuznets are also tested. Long-term relationships between the series are found and nominal devaluation exacerbates income inequality. Although economic growth appears to worsen income distribution, Kuznets ' (1955) inverted-U 
relationships show the nonlinear connection between variables. For Pakistan, this is long-term reassurance. FDI and trade openness often increase the distribution of incomes. Inflation decreases income inequality, but in Pakistan, unemployment worsens it.

According to Belloumi (2018), it is the purpose of this study, by implies time series data covering the period 1970-2013, to show the direction of causality between poverty, inequality and economic growth. This paper uses an ARDL-bound cointegration test method and an alteration of the Granger Causality test. The result of the bound tests shows that long-term relations between the variables are apparent. In the long run, we believe that the relationship between the disparity of income and poverty has been positive while in the short term, the relationship between inequality and growth to poverty is positive. Toda and Yamamoto's results show that the causal relationship from economic growth to poverty is unidirectional. Some studies show that the initial level of inequality and the growth rate are in a negative causal relationship in the long run but for this paper have study about the link between the growth, inequality and poverty for Tunisia and the result is Unidirectional causality between poverty and inequality has been identified. However, the results of this paper indicate that inequality and economic growth are bidirectionally causal.

Based on the results from Ucal, Haug, \& Bilgin (2016), it examines how short and long term income inequalities in Turkey could be affected by foreign direct investment (FDI) and other determinants. This paper applies the analysis method of ARDL (Auto-Regressive Distributed Lag), which is appropriate for small samples. The data cover from 1970 to 2008 . The results indicate that increased FDI inflows in Turkey have contributed to an increase in income inequality shortterm but not long-term. This corresponds to the literature that FDI appears to increase inequality initially. Increasing literacy rates and growth in GDP will lower inequalities in short and long terms. The impact of the literacy rate in the long term is particularly important statistically, and this is the short term impact of GDP growth. Nevertheless, population growth has a significantly negative impact on income inequality in the long term. This study suggests that GDP growth alone will be insufficient policies to reduce income inequality in the long term.

\section{Model Specification}

In this paper, the following model was adopted as follows:

ID = $f(G D P$, INF, CORR, FDI, TRADE) (1.0)

Where ID is inequality of income distribution as a proxy of GINI (\% of GINI), GDP is the gross domestic product (GDP per capita), INF is the inflation rate, CORR is corruption (annual \%), FDI is the foreign direct investment (\% of GDP), TRADE is trade openness (\% of GDP). All variables are expected to have positive or negative impacts on income distribution in Indonesia.

To test the stationarity of each variable, the log form of the variables was used. Log transformation can reduce the problem of heteroscedasticity because it compresses the scale in which the variables are measured, thereby reducing a tenfold difference between two values to twofold difference.

The log-linear form $(L N)$ of each variable in the above equation is shown as follows: 
$L N I D 2_{t}=\delta_{0}+\beta_{1} L N G D P_{1}+\beta_{2} L N I N F_{2}+\beta_{3} L N C O R R_{3}+\beta_{4} L N F D I_{4}+\beta_{5} L N T R A D E_{5}+\mu_{t}$ (2.0)

For consistent and efficient results, all the variables were transformed into natural logarithms $(L N)$ in order to produce elasticities outcomes as well as to reduce heteroscedasticity problem. The term $\varepsilon$ represents error term and the subscripts i and t denote country and time, respectively. The Unrestricted Error Correction Model (UECM) for equation (2.0) as follows: $\Delta L N I D_{t}=\beta_{0}+\theta_{0} L N I D_{t-1}+\theta_{1} L N G D P_{t-1}+\theta_{2} L N I N F_{t-1}+\theta_{3} L N C O R R_{t-1}+\theta_{4} L N F D I_{t-1}+$ $\theta_{5} L N T R A D E_{t-1}+\sum_{i-1}^{a} \beta_{i} \Delta L N I D_{t-i}+\sum_{i-0}^{b} \gamma_{i} \Delta L N G D O P_{t-i}+\sum_{i-0}^{c} \delta_{i} \Delta L N I N F_{t-i}+$ $\sum_{i-0}^{d} \vartheta_{i} \Delta L N C O R R_{t-i}+\sum_{i-0}^{e} \rho_{i} \Delta L N F D I_{t-i} \sum_{i-0}^{f} \tau_{i} \Delta L N T R A D E_{t-i}+\mu_{t}$

Where $\Delta$ is the first-difference operator, ut is a white-noise disturbance term. The above final model also can be viewed as an ARDL of order, ( $a b c d$ e). The model indicates that the income distribution can be influenced and explained by its past values, so it involves other disturbance. Hence, this model was modified in order to capture and absorb certain economic conditions. The structural lags are determined by using minimum Akaike's information criteria (AIC). From the estimation of ECMs, the long-run elasticities are the coefficient of the one lagged explanatory variable (multiplied by a negative sign) divided by the coefficient of the one lagged dependent variable. For example based on the final model, the long-run GINI, GDP, FDI, and INF elasticities are $(\beta 2 / \beta 1),(\beta 3 / \beta 1)$ and $(\beta 4 / \beta 1)$ respectively. The short-run effects are captured by the coefficients of the first differenced variables. After regression of Equation (3), the Wald test (Fstatistic) was computed to differentiate the long-run relationship between the variables. The Wald test can be shown by imposing restrictions on the estimated long-run coefficients of economic growth inflation, corruption, foreign direct investment, and trade openness.

Annual data over 34 years starting from 1984 until 2017 are used in the empirical analysis. The data have been collected from various sources. The sources of each data are listed in the following table:

Table 1: Source of Data

\begin{tabular}{lll}
\hline Model & Description & Sources \\
\hline ID & Inequality of Income Distribution (\% of GDP) & GCIP \\
GDP & Gross Domestic Product (\% of GDP) & WDI \\
INF & Inflation Rate, consumer price (annual \%) & WDI \\
CORR & Corruption (\% of GDP) & WBD \\
FDI & Foreign Direct Investment (\% of GDP) & WDI \\
TRADE & Trade Openness (\% of GDP) & WDI \\
\hline
\end{tabular}

WDI stands for World Development Indicator (2018) WBD stands for World Bank Development 2018, GCIP refer to Global Consumption Income Project (2018)

\section{Empirical Results and Discussion}

The analysis begins with testing the unit root of every variable for Malaysia. Unit root tests such as Dickey-Fuller (DF) / Augmented Dickey-Fuller (ADF) and the Phillip Perron (PP) are the two most common unit root used in detecting the stationarity of the data. 
Based on DF and ADF showed in Table 2, the results indicate that all variable shows mix evidence for at level and first different. Gross Domestic Product (GDP) and Inflation (INF) are significant at both level no trend and with the trend at a $1 \%$ significant level. For the first difference, all variables are found to be stationary for both no trend and with the trend. For the level no trend, the results show all variables are significant at $1 \%$ significant level. It is found that with the trend, most of the variables are significant at $1 \%$ significant level except for Foreign Direct Investment (FDI) that significant at $5 \%$ significant level.

Unit's root test it once again tested by a more powerful test known as the Phillip Perron test (PP). The result revealed that all variables at a level for both no trend and with the trend are most significant. At level, no trend, both gross domestic product (GDP) and inflation (INF) are significant at level $1 \%$ significant level. For the level with the trend, both gross domestic product (GDP) and inflation (INF) are also significant at $1 \%$ significant. However, at the first difference, all variables at no trend and with the trend are significant at a $1 \%$ significant level except for foreign direct investment (FDI) first difference with the trend is significant at $5 \%$ significant level. Therefore, the data meet the requirement to proceed by using the Autoregressive Distributed Lags (ARDL) module as suggested by Pesaran Shin and Smith (2001).

Table 2: ADF and PP Unit Root Test

\begin{tabular}{lcccc}
\hline \multicolumn{4}{c}{ DF/ADF Unit Root Test } & \multicolumn{3}{c}{ First Difference } \\
\cline { 2 - 5 } & No Trend & With Trend & No Trend & With Trend \\
LGINI & $-1.362(0)$ & $-1.640(0)$ & $-3.526(0)$ & $-3.464(0)$ \\
& $(0.589)$ & $(0.755)$ & $(0.014)^{* *}$ & $(0.061)^{*}$ \\
LGDP & $-6.768(0)$ & $-13.658(0)$ & $-6.676(0)$ & $-13.472(0)$ \\
& $(0.000)^{* * *}$ & $(0.000)^{* * *}$ & $(0.000)^{* * *}$ & $(0.000)^{* * *}$ \\
LINF & $-4.371(0)$ & $-4.302(0)$ & $-8.709(1)$ & $-8.756(1)$ \\
& $(0.002)^{* * *}$ & $(0.009)^{* * *}$ & $(0.000)^{* * *}$ & $(0.000)^{* * *}$ \\
LCORR & $-2.046(0)$ & $-2.743(0)$ & $-6.332(0)$ & $-6.226(0)$ \\
& $(0.267)$ & $(0.227)$ & $(0.000)^{* * *}$ & $(0.000)^{* * *}$ \\
LFDI & $-1.244(0)$ & $-1.574(0)$ & $-4.311(0)$ & $-4.239(0)$ \\
& $(0.643)$ & $(0.782)$ & $(0.002)^{* * *}$ & $(0.011)^{* *}$ \\
LTRADE & $-2.442(0)$ & $-2.622(0)$ & $-7.944(0)$ & $-8.188(0)$ \\
& $(0.139)$ & $(0.273)$ & $(0.000)^{* * *}$ & $(0.000)^{* * *}$ \\
\hline
\end{tabular}


PP Unit Root Test

\begin{tabular}{|c|c|c|c|c|}
\hline & \multicolumn{2}{|c|}{ Level } & \multicolumn{2}{|c|}{ First Difference } \\
\hline & No Trend & With Trend & No Trend & With Trend \\
\hline \multirow[t]{2}{*}{ LGINI } & $-1.533(3)$ & $-2.125(2)$ & $-3.316(22)$ & $-3.192(22)$ \\
\hline & $(0.505)$ & $(0.514)$ & $(0.022)^{* *}$ & (0.104) \\
\hline \multirow[t]{2}{*}{ LGDP } & $-6.669(3)$ & $-14.949(1)$ & $-6.592(3)$ & $-14.809(1)$ \\
\hline & $(0.000)^{* * *}$ & $(0.000)^{* * *}$ & $(0.000)^{* * *}$ & $(0.000) * * *$ \\
\hline \multirow[t]{2}{*}{ LINF } & $-4.375(0)$ & $-4.551(2)$ & $-13.370(21)$ & $-26.993(31)$ \\
\hline & $(0.002)^{* * *}$ & $(0.005)^{* * *}$ & $(0.000)^{* * *}$ & $(0.000) * * *$ \\
\hline \multirow[t]{2}{*}{ LCORR } & $-1.958(2)$ & $-2.856(3)$ & $-6.346(1)$ & $-6.238(1)$ \\
\hline & $(0.303)$ & (0.189) & $(0.000)^{* * *}$ & $(0.000) * * *$ \\
\hline \multirow[t]{2}{*}{ LFDI } & $-1.398(1)$ & $-1.762(1)$ & $-4.293(2)$ & $-4.219(2)$ \\
\hline & $(0.571)$ & $(0.670)$ & $(0.002)^{* * *}$ & $(0.011)^{* *}$ \\
\hline \multirow[t]{2}{*}{ LTRADE } & $-2.380(3)$ & $-2.471(3)$ & $-8.043(1)$ & $-9.619(4)$ \\
\hline & $(0.155)$ & $(0.339)$ & $(0.000)^{* * *}$ & $(0.000) * * *$ \\
\hline
\end{tabular}

ARDL testing begins with testing the existence of a long-run relationship between the dependent variable and independent variables. Table 3 below illustrates the result of F-statistic or Indonesia by setting the maximum lag equal to 4 . Based on the result, the optimum lag was obtained by using Akaike Information Criteria (AIC). AIC in the Table implied that the optimum orders were 1, $1,2,1,0,2$. The F-statistic needs to be compared with the critical value provided by Narayan (2004). The results of cointegration show that the F-statistic obtained from the optimum lag is greater than the upper bound critical value. For example, the F statistic 4.005952 is greater than the upper bound value at $5 \%$ significant level. Thus, it is confirmed that there is an existence of a long-run relationship between the variables.

Table 3: F-statistic for Testing the Existence of Long Run Equation

\begin{tabular}{|c|c|c|c|c|}
\hline Model & & $\begin{array}{l}\text { Max } \\
\text { Lag }\end{array}$ & Lag order & F statistics \\
\hline $\begin{array}{l}\text { LGINI } \\
\text { F(LGDP,LNINF,LCORR,LFDI,LTRADE) }\end{array}$ & $=$ & $(2,1)$ & $(1,1,2,1,0,2)$ & $4.006 * *$ \\
\hline Critical Values for $F$ stat & & & Lower I(0) & Upper (1) \\
\hline $10 \%$ & & & 2.26 & 3.35 \\
\hline $5 \%$ & & & 2.62 & 3.79 \\
\hline $1 \%$ & & & 3.41 & 4.68 \\
\hline
\end{tabular}

Note: 1. \# the critical values are based on Pesaran et al. (2001), case III: unrestricted intercept, and no trend. 2 . $\mathrm{k}$ is a number of variables and it is equivalent to $5.3 . *, * *$, and $* * *$ represent $10 \%, 5 \%$, and $1 \%$ level of significance, respectively. 
Before the result was analyzed, it is important to check the robustness of the model by adopting several diagnostic tests such as Breusch-Godfrey serial correlation LM test, ARCH test, JacqueBera normality test, and Ramsey RESET specification test. All tests showed that the model has the desired econometric properties, namely, it has a correct functional form and the model's residuals are serially uncorrelated, and homoscedastic given that the probability value of the ttest is all above than $10 \%$ significant value.

Table 4: Diagnostic Checking

\begin{tabular}{ll}
\hline Test Statistic & F-statistic \\
\hline Jarque-Bera & $1.808(0.404)$ \\
Breusch-Godfrey Serial Correlation & $1.005(0.386)$ \\
Heteroskedasticity Test & $0.476(0.904)$ \\
Ramsey RESET stability & $4.149(0.056)$ \\
\hline
\end{tabular}

Note. $1 .{ }^{* *}$ represent $5 \%$ significant levels. 2 . The diagnostic test performed as follows A. Lagrange multiplier test for residual serial correlation; B. Ramsey's RESET test using the square of the fitted values; C. Based on a test of skewness kurtosis of residuals; D. Based on the regression of squared fitted values. 2 .

For this research, both the stability test has been conducted and the outcome is given in Figure 2. The plot of the CUSUM test as shown in Figure 2 revealed that the residuals are within two polar bounds at significance level. Moreover, the plot of the CUSUMSQ test stays within two polar bounds at the $5 \%$ significance level. This is confirming that the selected time series model is stable structurally.

Figure 2: Cumulative Sum of Recursive Residual (CUSUM) and Cumulative Sum of Squares of Recursive Residuals (CUSUMSQ)

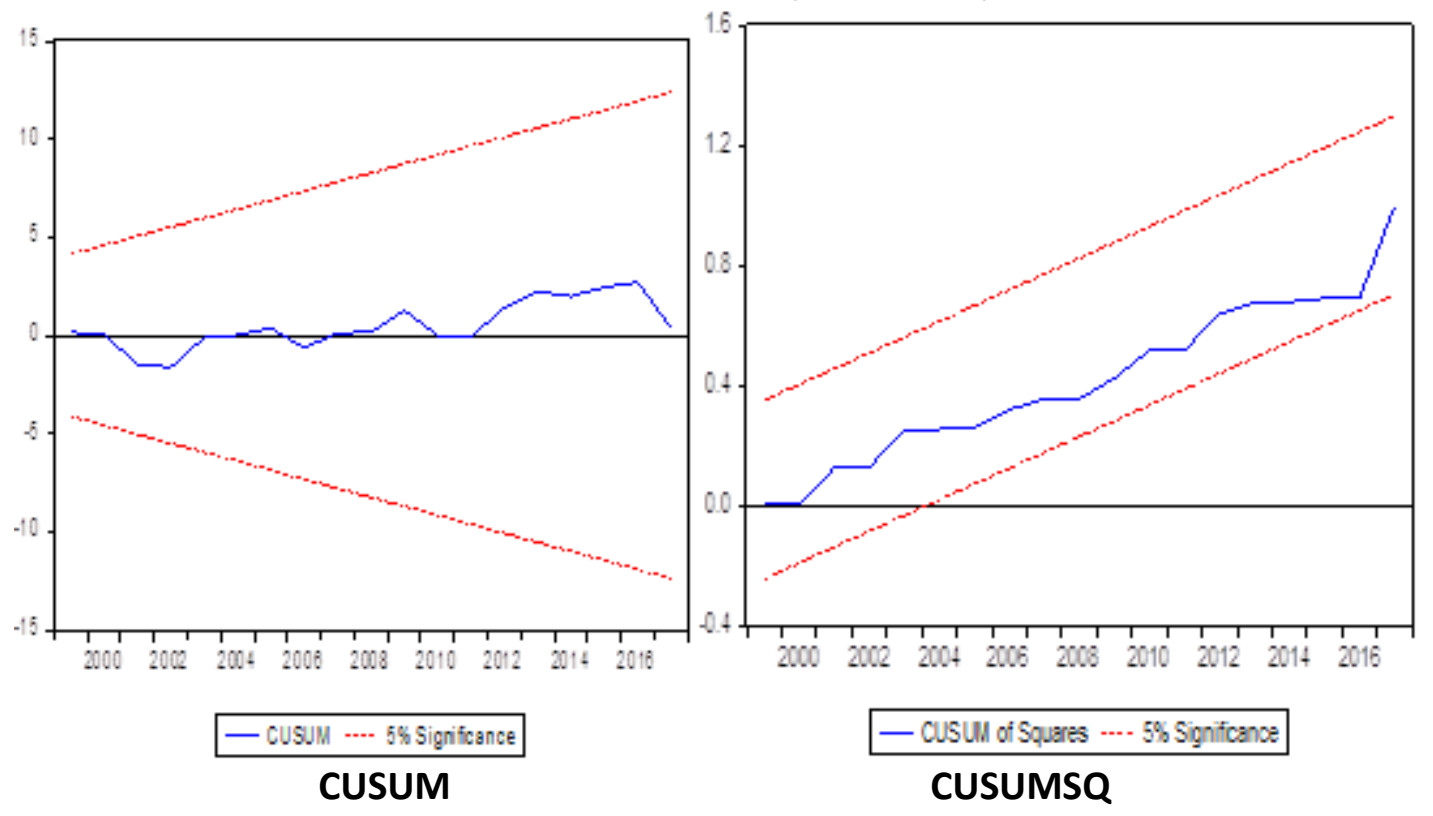


INTERNATIONAL JOURNAL OF ACADEMIC RESEARCH ECONOMICS AND MANAGEMENT SCIENCES Vol. 9, No. 2, 2020, E-ISSN: 2226-3624 @ 2020 HRMARS

\section{Long-Run Elasticities and Short-Run Dynamic}

The Cointegration of two or more than two-time series variables implies that there exists an equilibrium or long-run relationship between them. Table 4A reports the empirical verdicts of long-run relations among regressors of the proposed $\operatorname{ARDL}$ model $(1,1,2,1,0,2)$.

The estimated coefficients of the long-run relationship between Inequality of Income Distribution and the independent variables significant at 1\% level for Foreign Direct Investment (FDI), while $5 \%$ for Corruption (CORR) and Trade Openness (TRADE) and 10\% for Gross Domestic Product (GDP). The result shows that the Gross Domestic Product (GDP) has a negative relationship with the Inequality of Income Distribution with estimated elasticities of 0.15 respectively. This shows that a $1 \%$ increase in Gross Domestic Product (GDP) will result in a $0.15 \%$ decrease in the inequality of income distribution. According to Leigh and van der Eng (2009), it is calculated that the per capita GDP has a major long-term negative effect on income inequality. In addition, they suggest that it is important to achieve sectoral disparities in the relationship between growth and inequality, to reveal the drivers of growth types that increase inequality significantly in Indonesia. High levels of income inequality can hurt the sustainability of Indonesian economic growth. Next, corruption with estimated elasticities 0.05 indicates that a $1 \%$ increase in corruption leads to about $0.05 \%$ increase in Inequality of Income Distribution. Based on Murphy, Shleifer, and Vishny (1991, 1993), corruption has an inverted U-shaped effect on the Gini coefficient that means that inequality is low where corruption is high or low, but inequality is high when it is intermediate. Corruption raises income inequality to a lesser extent in countries with higher government spending. For the FDI, it has a negative relationship with the inequality of income distribution with estimated elasticities of 1.18 respectively. This shows that a $1 \%$ increase in foreign direct investment (FDI) will result in a $1.18 \%$ decrease in the inequality of income distribution. According to Celik and Basdas (2010) examine the impact of globalization, both for developed and developing countries, on income inequality. The results show that the external FDI and GINI coefficients have a negative relationship. Besides they suggest obtaining a full assessment of the economic effects of service offshoring on developing countries the negative impact of FDI on income inequality should be compared to the positive role of captive centers in promoting economic development, through for example spillovers. Lastly, for the trade openness (TRADE), it has a negative relationship with estimated elasticities 0.3 indicates that a $1 \%$ increase in trade openness leads to about $0.3 \%$ increase in inequality of income distribution.

Based on the short-run elasticities as revealed in Table 4B indicate that in the short term, the trade openness has a negative impact significantly on income inequality. The outcome of the study from FEVD does not make a significant contribution to trade openness in Indonesia to the reduction of income inequality. Economic growth is the aspect that makes a significant difference. In the long term, however, economic growth aggravates income inequality. Even if equitable economic growth is established, income inequality can be minimized so that the whole

of society gets its outcome. Fairtrade should also be carried out where an equal partnership between the economic players takes place, which is the reference in trade rules based on spirit and soul (cooperation). 
INTERNATIONAL JOURNAL OF ACADEMIC RESEARCH ECONOMICS AND MANAGEMENT SCIENCES

Vol. 9, No. 2, 2020, E-ISSN: 2226-3624 @ 2020 HRMARS

Table 4A: Long Run Coefficients

Panel A: Long run elasticities $(\mathbf{1 , 1 , 2 , 1 , 0 , 2 )}$

\begin{tabular}{ccccc}
\hline Variable & Coefficient & T-Statistic & Probability & Standard Error \\
\hline InGDP & -0.147 & -1.799 & 0.088 & 0.082 \\
InINF & -0.017 & -0.255 & 0.802 & 0.068 \\
InCORR & 0.045 & 2.233 & 0.038 & 0.020 \\
InFDI & -1.178 & -6.059 & 0.000 & 0.194 \\
InTRADE & -0.295 & -2.150 & 0.045 & 0.137 \\
C & 2.571 & 4.297 & 0.000 & 0.598 \\
\hline
\end{tabular}

Note: $\left({ }^{*}\right),\left({ }^{* *}\right),\left({ }^{* * *}\right)$ indicate significant at $10 \%, 5 \%$ and $1 \%$ significance level respectively. DV is dependent variable, IV is independent variable.

The ECM proposed by Engle and Granger is a method for the long-term analysis of the short term behavior of a variable. If the economic variables are shown to be co-integrated, long-term reversal disturbances can be introduced, so that the error correction model can be tested empirically, long-term and short-term effects can be studied and the adjusted coefficient can be seen. Based on the table below, the estimated lagged error correction term (ECT) in ARDL regression for model estimates appear to be negative and statistically significant, which are features necessary for model stability. The ECT value is -0.5628 or $56.28 \%$ of the adjustment are completed in a year due to short-run adjustment.

Table 4B: Short-run Coefficients

Panel B: Short run elasticities $(\mathbf{1 , 1 , 2 , 1 , 0 , 2 )}$

\begin{tabular}{ccccc}
\hline Variable & Coefficient & T-Statistic & Probability & Standard Error \\
\hline D(LNGDP) & -0.044 & -1.659 & 0.114 & 0.027 \\
D(LNINF) & 0.033 & 1.350 & 0.193 & 0.024 \\
D(LNINF(-1)) & 0.042 & 2.358 & 0.029 & 0.018 \\
D(LNCORR) & 0.007 & 0.529 & 0.603 & 0.013 \\
D(LNFDI) & -0.663 & -3.071 & 0.006 & 0.216 \\
D(LNTRADE) & 0.026 & 0.461 & 0.650 & 0.056 \\
D(LNTRADE(-1)) & 0.206 & 2.308 & 0.032 & 0.089 \\
CointEq(-1) & -0.563 & -3.658 & 0.002 & 0.154 \\
\hline
\end{tabular}

Notes: ${ }^{*}$, and $* * *$ indicate significant at $1 \%$, and $10 \%$ significant level respectively.

\section{Conclusion and Policy Recommendation}

The objective of this paper is to examine the impact of selected macroeconomic variables on Inequality of income distribution in Indonesia from 1984 to 2017. There are several previous studies investigated the connection between independent and dependent variables using various methodologies. For this study, the selected macroeconomics variables include gross domestic product, inflation, corruption, foreign direct investment, and trade openness. The test result of the unit root illustrates that the selected macroeconomic variables under consideration are mixed stationary. The Autoregressive Distributed Lag (ARDL) model of cointegration has been applied to find out the long-run relationship between selected macroeconomic variables that are included in this empirical review. The findings propose that there exists a long-run correlation 
between gross domestic product, corruption, foreign direct investment, and trade openness toward inequality of income distribution in Indonesia. Whereas, the result of the ARDL model exposes that all variables except for inflation have significantly influence inequality of income distribution in Indonesia. Based on the above empirical results, we recommend some policy steps in order to reduce the inequality of income distribution in Indonesia. The government must take serious action from these findings. There is the urgent that government needs to initiate policies that will facilitate the improvement of the GINI coefficient. First by providing additional subsidies to reduce the lower-income burden. Government subsidies tend to be high in many countries, frequently equal to a few percentage points of GDP. Consumer conduct is enabled by a demand subsidy. In developing countries where governments subsidize food, water, electricity, and education, all of these benefits are most often based on the fact that basic requirements are required regardless of how bad they are. Secondly, Indonesia's Corruption Eradication Commission or KPK needs to fight corruption to ensure that local governments are more effective, fair, and efficient. It is, therefore, necessary to counter corruption in Indonesia by removing government intervention, improving education (quantity and quality), improving the investment climate to attract more foreign investment, and, finally, through the integration of the international economy. Thirdly, to increase the trade openness, the Ministry of the Trade Republic of Indonesia needs to make the budget fairly to ensure not overspending. Other than that, they need to export more rather than import product because export is income for the country and can lead to good economic growth. Lastly, to increase the foreign direct investment, Indonesia Investment Promotion Agency targeted and maybe the link between adequate foreign investors and the domestic economy. It should serve as a one-stop-shop on the one hand for demand from the host country from the investors.

\section{References}

Atkinson, A. B. (1997). Bringing income distribution in from the cold. The Economic Journal 107, $297 \tilde{n} 321$.

Atkinson, Anthony B., \& Brandolini, A. (2001). Promise and pitfalls in the use of "secondary" data sets: Income inequality in OECD countries as a case study. Journal of Economic Literature 39: 771-99.

Bourguignon, F. (1979). Decomposable income inequality measures. Econometrica: Journal of the Econometric Society. 901-920.

Deyshappriya, N. P. R. (2017). ADBI Working Paper 696. Tokyo: Asian Development Bank Institute.

Fatimah, N., \& Zaidi, M. A. S., \& Noorasiah, S. (2017). Long run relationship between income inequality and economic growth: Evidence from Malaysia. International Journal of Academic Research in Business and Social Sciences. 7. 10.6007/JJARBSS/v7-i6/2945.

Guidetti, G., \& Rehbein, B. (2017). Theoretical approaches to inequality in economics and sociology. Inequality in Economics and Sociology: New Perspectives, (1863), 7-29.

Global Consumption and Income Project (GCIP). (2018). Income Inequality Dataset. Available online: http://gcip.info/graphs/download (Accessed on 5 March 2018).

Khemili, H., \& Belloumi, M. (2018). Cointegration relationship between growth, inequality and poverty in tunisia. International Journal of Applied Economics, Finance and Accounting, 2(1), 8-18. 
Kuznet, S. (1955). Economic growth and income inequality simon kuznets. American Economic Review, 45(1), 1-28.

Leigh, A., \& Van der Eng, P. (2009). Inequality in Indonesia: What can we learn from top incomes? Journal of Public Economics, 93(1-2), 209-212.

Li, H., Xu, L. C., \& Zou, H. (2000). Corruption, income distribution, and growth. 12(2), 155181.

McKinsey Global Institute. (2012). The archipelago economy: Unleashing Indonesia's potential. McKinsey\&Company. http://www.mckinsey.com/insights/ Asia pacific/the_archipelago_economy (accessed 30 January 2017).

Muhammad, S., Faridul, I., \& Sabihuddin, B. M. (2011). Devaluation and income inequality: Evidence from Pakistan. (35522), 1-16.

Murphy, K. M., Shleifer, A., \& Vishny, R. W. (1993), Why is rent-seeking so costly to growth? American Economic Review, May, 409-414.

Murphy, K., Shleifer, A., \& Vishney, R. (1991), The allocation of talent: implication for growth. Quarterly Journal of Economics 105, 503-30.

Narayan, P. K. (2004). Do public investments crowd out private investments? Fresh evidence from Fiji. Journal of Policy Modeling 26: 747-53.

Pesaran, M. H., \& Pesaran, B (1997). Working with Microfit 4.0: Interactive Econometric Analysis. Oxford, Oxford University Press.

Thalassinos, E., Uğurlu, E., \& Muratoğlu, Y. (2012). Income inequality and inflation in the EU. European Research Studies Journal, 15(1), 127-140.

Ucal, M., Haug, A. A., \& Bilgin, M. H. (2016). Income inequality and FDI: Evidence with Turkish data. Applied Economics, 48(11), 1030-1045.

Vo, D., Nguyen, T., Tran, N., \& Vo, A. (2019). What factors affect income inequality and economic growth in middle-income countries? Journal of Risk and Financial Management, 12(1), 40.

World Development Indicators. (2018), World Development Indicators. Washington, DC: The World Bank. Available form: http://www.databank.worldbank.org/data/reports.aspx?source=worlddevelopmentindicators. [Last accessed on 2018 Jan 07]. 